\title{
Výběr z aktuální české a slovenské literatury
}

BĚLOVSKÝ, P. Obligace z kontraktu. Smlouva a její vymahatelnost v ř́mském právu. Praha: Auditorium, 2021, 360 s. ISBN 978-80-87284-86-5.

ENGLIŠ, K. Vzpomínky na T. G. Masaryka. Brno: Masarykova univerzita, 2021, 63 s. ISBN 978-80-210-9790-2.

ENGLIŠ, K. Tož poslouchejte, jak jsme budovali republiku. Brno: Masarykova univerzita, 2021, 251 s. ISBN 978-80-210-9867-1; 978-80-210-9868-8 (online; pdf).

GREGOR, M. Historiografia rímskeho práva na Slovensku: Príbeh štyroch profesorov. Praha: Leges, 2021, 363 s. ISBN 978-80-7502-485-5.

HALÁSZ, I. Republika so Svätou korunou? Svätá koruna, idea republiky a historická ústava v mad'arskom právnom poriadku. Praha: Ústav státu a práva AV ČR, v. v. i., 2020, 132 s. ISBN 978-80-87439-49-4.

HORÁK, O. - RAZIM, J. Dějiny kodifikace soukromého práva v českých zemích. Praha: Leges, 2021, 160 s. ISBN 978-80-7502-501-2.

KOUDELKA, Z. Jaroslav Krejčí. Protektorátni premiér a predseda ústavního soudu. Praha: Leges, 2021, 146 s. ISBN 978-80-7502-475-6.

LYSÝ, M. Slovenské právne dejiny I. Šamorín: Heuréka, 2021, $191 \mathrm{s.}$ ISBN 978-80-8173-114-3.

NĚMEČKOVÁ D. a kol. Lidová spravedlnost. Mimořádné lidové soudy v letech 1945-1948. Praha: Auditorium, 2017, 580 s. ISBN 978-80-87284-68-1.

SCHELLE, K. - BEŇA, J. - TAUCHEN, J. Ústava a ústavní systém meziválečného Československa. Ostrava: KEY Publishing, 2020, 931 s. ISBN 978-80-7418-330-0.

SCHELLE, K. - VOJÁČEK, L. - TAUCHEN, J. Právněhistorická věda. Ostrava: Key publishing, 2021, 96 s. ISBN 978-80-7418-362-1.

STARÝ, M. Agent, který se neprostřilel ... a ti ostatní. Příspěvek k dějinám třetího odboje a politických procesư. Praha: Auditorium, 2020, 352 s. ISBN 978-80-87284-83-4. VACEK, J. Sexuální delikty před Apelačním soudem v letech 1687-1727. Praha: Academia, 2021, 186 s. ISBN 978-80-200-3226-3.

doi: 10.14712/2464689X.2021.35 